Koptiew, D., Puzio-Wacławik, B. (2019). Spółdzielnia socjalna jako innowacyjna forma działalności w zakresie rozwiązywania problemów społecznych. W: N. Laurisz, A. Pacut (red.). Ekonomia Społeczna. Innowacyjność społeczna w Polsce (s. 49-59). Kraków: Uniwersytet Ekonomiczny w Krakowie.

https://doi.org/10.15678/ES.2019.2.05

\title{
Spółdzielnia socjalna jako innowacyjna forma działalności w zakresie rozwiązywania problemów społecznych
}

\author{
Dorota Koptiew, Bogusława Puzio-Wacławik
}

Streszczenie: Ekonomia społeczna, jak i innowacje społeczne to zagadnienia, które przenikają się są instrumentem przydatnym przy rozwiązywaniu problemów o charakterze społeczno-gospodarczym. W tekście podjęto tematykę rozwiązywania problemów społecznych za pomocą spółdzielni socjalnych w Polsce. Skupiono się na roli spółdzielni socjalnych jako podmiotów ekonomii społecznej mających istotne znaczenie w reintegracji społecznej. Celem opracowania jest ocena wybranych aspektów dotyczących potencjału działania spółdzielni społecznych w Polsce. Zastosowane metody badawcze to analiza piśmiennictwa krajowego - publikacji naukowych oraz dokumentów rządowych dotyczących spółdzielczości socjalnej. W konkluzji stwierdzono, że koncepcja spółdzielni socjalnych stanowi innowacyjne podejście do rozwiązywania problemów społecznych, szczególnie na lokalnych rynkach pracy i przy przeciwdziałaniu niedoborom usług społecznych. Jednak jak wynika z badań skuteczność spółdzielczości socjalnej obniżona jest na skutek trudnej sytuacja finansowej tych podmiotów i występowanie licznych barier o charakterze wewnętrznym i zewnętrznym, na które napotykają w swej działalności.

Słowa kluczowe: ekonomia społeczna; spółdzielnia socjalna; innowacje społeczne; osoby wykluczone; reintegracja Kody JEL: J79; L73

\section{Wprowadzenie}

Celem opracowania jest analiza potencjału spółdzielni socjalnych w Polsce, które mają sprzyjać rozwiązywaniu lokalnych problemów zgodnie z wytycznymi określonymi w Krajowym Programie Rozwoju Ekonomii Społecznej do roku 2023 (MRPiPS, 2019, s. 54). Spółdzielczość socjalna skierowana jest do grup defaworyzowanych, a więc tych, które są słabsze na rynku pracy. Osoby długotrwale bezrobotne, niepełnosprawne, obciążone chorobą psychiczną czy będące w trakcie lub tuż po zakończeniu leczenia uzależnień, potrzebują nie tylko odpowiednich miejsc pracy, ale także działań o charakterze reintegracyjnym na płaszczyźnie społecznej i zawodowej.

Spółdzielnie socjalne są nie tylko miejscem zatrudnienia osób zagrożonych wykluczeniem społecznym, ale również dostarczycielem usług społecznych dla lokalnych społeczności, co odróżnia je od innych form przedsiębiorstw. Biorąc pod uwagę możliwości zatrudnienia słabszych grup, przedsiębiorstwa społeczne stanowią formę innowacyjną w stosunku do standardowych przedsiębiorstw. Dualny charakter celów realizowany przez te podmioty generuje wysoki poziom oczekiwań w stosunku do tej grupy podmiotów ekonomii społecznej w Polsce. 
W opinii autorek priorytetem prowadzonych badań w zakresie działalności podmiotów ekonomii społecznej, w tym spółdzielni socjalnych powinno być: rozmieszczenie i dynamika wzrostu liczby podmiotów, ich kondycja finansowa oraz analiza endo- i egzogenicznych barier w działalności. Sama forma prowadzenia działalności gospodarczej i zatrudnianie osób wykluczonych wydaje się przejawem innowacyjnego podejścia do rozwiązywania problemów społecznych, jak i problemów rynku pracy w zakresie wspierania grup defaworyzowanych, ale warto bliżej przyjrzeć się i dokonać oceny różnych aspektów funkcjonowania spółdzielni socjalnych w Polsce.

Opracowanie ma na celu analizę potencjału spółdzielni socjalnych w Polsce w rozwiązywaniu problemów społecznych. W początkowej części tekstu przedstawiono przegląd literatury na temat innowacji społecznych oraz przedsiębiorstw społecznych. W dalszej części zaprezentowano metodologię badań, a następnie ich wyniki przedstawiające sytuację spółdzielni socjalnych w Polsce w świetle innowacji społecznych. Opracowanie kończą konkluzje podsumowujące rozważania.

\section{Przegląd literatury}

W literaturze nauk społecznych istnieje wiele definicji innowacji społecznych. Według R. Praszkiera i A. Nowaka (2005, s. 140-157) innowacje społeczne są to:

- nowe idee, które mają racje bytu i pozwalają na osiąganie celów społecznych, które odróżniają innowacje od ulepszeń, które przejawiają się tylko stopniowo w zmianach społecznych oraz różnią się też od kreatywności i inwencji;

- tworzenie i wdrażanie nowych idei w zakresie organizowania działalności lub stosunków społecznych w celu osiągnięcia wspólnych celów.

Innowacje społeczne przejawiają się w kontekście pięciu następujących obszarów (Wronka-Pośpiech, 2015, s. 124-136):

- transformacji społecznej - przejawia się on w formie społeczeństwa obywatelskiego, w procesie przemian społecznych oraz wzrostu roli ekonomii społecznej. Ważnym czynnikiem tego obszaru innowacji jest udział biznesu w zmianie społecznej (społeczna odpowiedzialność biznesu) i przedsiębiorstw w prowadzeniu kolejnej fali innowacji.

- modelu zarządzania organizacją uwzględniającego budowanie strategii biznesowych obejmujących innowacyjne zmiany w kapitale ludzkim, instytucjonalnym i społecznym, które prowadzą do poprawy sprawności organizacyjnej i poprawy konkurencyjności oraz poprawy zarządzania zasobami ludzkimi.

- przedsiębiorczości społecznej, polegającej na rozwoju nowych i innowacyjnych sposobów pokonywania trudnych wyzwań społecznych poprzez zaangażowanie przedsiębiorców „wrażliwych społecznie”.

- produkcji nowych produktów i usług; tworzenia programów zaspokajających potrzeby społeczne, innowacyjnych w sektorze publicznym oraz świadczenia usług publicznych przez przedsiębiorstwa społeczne i organizacje społeczeństwa obywatelskiego.

- modelu zarządzania polegającego na wzmocnieniu pozycji i zwiększeniu zdolności instytucji społecznych, w tym poprawie wzajemnych relacji pomiędzy różnymi podmiotami społecznymi, poprawie umiejętności, kompetencji i kapitału społecznego wśród aktorów życia społecznego zaangażowanych w rozwój i realizację programów oraz strategii społecznych i gospodarczych. 
W opinii wielu autorów (por. Skubiak, 2016; Szczepańczyk, 2017; Jędrych, 2013) możliwości wykorzystania innowacji społecznych są bardzo różnorodne i mogą dotyczyć wielu obszarów życia społeczno-gospodarczego. Przykładowo w dziedzinie edukacji Tafel-Viia i in. (2012) analizowali mechanizmy wpływające na reformę edukacji i dostrzegli m.in., że nauka w oparciu o networking wśród nauczycieli wpływa na skuteczne wdrażanie nowych metod nauczania. Z kolei w dziedzinie ochrony środowiska Maruyama, Nishikido i lida (2007) wskazują na wpływ aktywnego uczestnictwa w życiu obywatelskim na akceptowanie nowych rozwiązań technologicznych związanych m.in. z energią odnawialną. Niektórzy autorzy skupili się na sposobach wykorzystywania innowacji społecznych do promowania zmian społecznych w celu zmniejszenia przemocy wobec kobiet (Sullivan, 2003) lub pomocy osobom bezdomnym cierpiącym na choroby psychiczne (Calsyn, 2003).

Wspólnym elementem wielu definicji innowacji społecznych jest podejście, które akcentuje ich rolę w nowatorskim rozwiązywaniu problemów społecznych i umożliwieniu wykorzystania potencjału tkwiącego w społeczeństwie obywatelskim. Innowacje o charakterze społecznym mogą być skutecznym narzędziem pobudzania do działania wcześniej marginalizowanych grup, zaspokajania potrzeb pojedynczych jednostek, a oparte są na oryginalnym wykorzystaniu posiadanych zasobów, jak i na angażowaniu partnerów reprezentujących różne sektory gospodarki w celu rozwiązywania istotnych dla danej społeczności problemów (Morawska-Jancelewicz, 2016, s. 6).

W tym kontekście warto zwrócić uwagę w szczególności na koncepcję ekonomii społecznej i wydzielone w jej ramach przedsiębiorstwa społeczne. Reprezentują one nowe podejście do sposobu prowadzenia działalności gospodarczej z uwzględnieniem celów społecznych, które sprzyja włączeniu społecznemu i tworzeniu miejsc pracy dla grup defaworyzowanych. Jedną z przywoływanych definicji, jest ta opracowana przez J. Pearce’a, według której „przedsiębiorstwo społeczne" to ogólne określenie podmiotów gospodarczych, które mają społeczny cel, nie są zorientowane na tworzenie i dystrybucję kapitału oraz mają demokratyczną, wymierną i opartą na wspólnym zarządzaniu strukturę (Pearce, 2003, s. 190). Inne podejście proponuje D. Góźdź, według której jest to element każdego z wszystkich trzech sektorów gospodarki, ze względu na to, że działa na rzecz dobra publicznego, często w sferze usług publicznych, z silnym poczuciem misji społecznej, ale stosując zasady myślenia biznesowego (Góźdź, 2008, s. 205). W opinii J. Hausnera i N. Laurisza przedsiębiorstwo społeczne jest kluczowym ogniwem ekonomii społecznej. Jego funkcją jest nie tylko wytwarzanie określonych dóbr i usług, ale też mobilizacja kapitału społecznego, generowanie innowacyjności oraz poszerzanie rynku przez włączanie do uczestnictwa w nim osób dotychczas wykluczonych. Mimo że jest ono częścią gospodarki rynkowej, to jednak lokuje swoją misję i cele poza rynkiem (Hausner, Laurisz, 2006, s. 9).

Wszystkie cechy wymagane od przedsiębiorstw społecznych, tj. zdolność do aktywizacji i reintegracji osób zagrożonych wykluczeniem społecznym; koncentrowanie się na potrzebach społeczności lokalnych; działanie na rzecz dobra wspólnego przez dostarczanie usług społecznych użyteczności publicznej oraz realizację zadań publicznych w zakresie rozwoju lokalnego; samodzielność, samopomoc i samowystarczalność (MRPiPS, 2019, s. 21), wypełnia najmłodsza grupa organizacji w sektorze spółdzielczym, tj. spółdzielnia socjalna. Instytucja ta pojawiła się w polskim porządku prawnym w 2006 r., wprowadzona ustawą z dnia 27 kwietnia 2006 r. o spółdzielniach socjalnych (Ustawa..., 2006). Przedmiotem działalności spółdzielni socjalnej jest prowadzenie wspólnego przedsiębiorstwa w oparciu o osobistą pracę członków. Spółdzielnia socjalna działa na rzecz: 
- społecznej reintegracji jej członków, przez co należy rozumieć działania mające na celu odbudowanie i podtrzymanie umiejętności uczestniczenia w życiu społeczności lokalnej i pełnienia ról społecznych w miejscu pracy, zamieszkania lub pobytu.

- zawodowej reintegracji jej członków, przez co należy rozumieć działania mające na celu odbudowanie i podtrzymanie zdolności do samodzielnego świadczenia pracy na rynku pracy - a działania te nie są wykonywane w ramach prowadzonej przez spółdzielnię socjalną działalności gospodarczej.

Współczesne zmiany społeczno-gospodarcze generują problemy, którym nie zawsze są w stanie sprostać działania organów administracji państwowej czy samorządowej, inicjatywy legislacyjne lub szeroko zakrojone działania systemowe. Pomocy w ich rozwiązaniu, zwłaszcza na poziomie lokalnym, można upatrywać ze strony spółdzielni socjalnych, pod warunkiem, że funkcjonują one w sposób pozwalający na skuteczne działania w tych obszarach.

\section{Metoda badawcza}

Dobór metod badawczych i materiałów źródłowych został podporządkowany głównemu celowi opracowania. Ważną częścią badań była analiza publikacji związanych z innowacjami społecznymi, problematyką przedsiębiorstw społecznych i spółdzielczością socjalną. Kolejnym elementem badań była także ocena przetworzonych informacji i danych statystycznych uzyskanych z opracowań Departamentu Ekonomii Społecznej i Solidarnej Ministerstwa Rodziny, Pracy i Polityki Społecznej, Krajowego Rejestru Sądowego, Ogólnopolskiego Związku Rewizyjnego Spółdzielni Socjalnych, Ośrodków Wspierania Ekonomii Społecznej oraz cyklicznych informacji Rady Ministrów o funkcjonowaniu spółdzielni socjalnych (np. Informacja o funkcjonowaniu spółdzielni..., 2012, 2015, 2016, 2018).

\section{Prezentacja wyników badania i ich omówienie}

Zmieniająca się sytuacja społeczno-gospodarcza w Polsce powoduje konieczność zmian w metodach działania sprzyjających rozwojowi i powoduje, że wymagają one innowacyjnego podejścia. Obecne realia determinowane są przez takie czynniki jak:

- rosnące braki w zasobach pracy;

- polaryzacja terytorialna, utrzymywanie się obszarów trwałej marginalizacji zarówno społecznej i gospodarczej;

- pogłębianie się procesu starzenia społeczeństwa;

- niestabilność i niska jakość zatrudnienia;

- niedobór usług społecznych i rosnące potrzeby gospodarki obiegu zamkniętego.

Remedium na te deficyty można upatrywać w sektorze przedsiębiorstw społecznych, ze spółdzielniami socjalnymi na czele (Ekonomia społeczna w Polsce..., 2019, s. 12).

Do tej pory wypełniały one zadania związane z tworzeniem miejsc pracy dla grup defaworyzowanych. Obecnie trzeba spojrzeć szerzej na rolę spółdzielni socjalnych w rozwiązywaniu problemów społecznych, ze szczególnym uwzględnieniem konieczności rozwiązywania różnorodnych problemów osób nieaktywnych zawodowo. Prognozowane braki w zasobach pracy do 2040 r. szacowane na 4,5 mln osób (Związek Przedsiębiorców i Pracodawców, 2016, s. 13) wymagają aktywizowania osób dotychczas nieaktywnych zawodowo na rynku pracy lub aktywizowania osób bezrobotnych najbardziej oddalonych od rynku pracy. 
Zjawisko starzenia się społeczeństwa jest wyzwaniem nie tylko demograficznym, ale też społecznym i gospodarczym. Zgodnie z przewidywaniami problem ten spowoduje ogromny wzrost liczby osób w wieku 65 lat i więcej (wzrośnie ona o 5,4 mln w porównaniu do 2013 r. i do końca 2050 r. będzie wynosiła ponad $11 \mathrm{mln}$ ), a tym samym osoby w wieku 65 lat i więcej będą stanowiły prawie 1/3 ogółu ludności Polski (Prognoza ludności..., 2014). Skutkować to będzie wzrostem zapotrzebowania na produkty i usługi dla seniorów, a także koniecznością rozwijania rożnych form usług opiekuńczych i wspomagających osoby o ograniczonej samodzielności oraz poszukiwanie nowych sposobów dostarczenia usług opiekuńczych (Ibidem). Dołączając do tego deficyt usług o charakterze społecznym oraz związanych z gospodarką obiegu zamkniętego (np. selektywne zbierania odpadów, recykling, utrzymanie czystości i porządku itp.) otwiera się pole do działania spółdzielni socjalnych lub innych podmiotów ekonomii społecznej. Powodzenie tego przedsięwzięcia uzależnione jest jednak od liczby, efektywności działania i kondycji finansowej tych podmiotów.

Liczba spółdzielni socjalnych w Polsce systematycznie rośnie, ale dynamika tego wzrostu jest zróżnicowana (wykres 1).

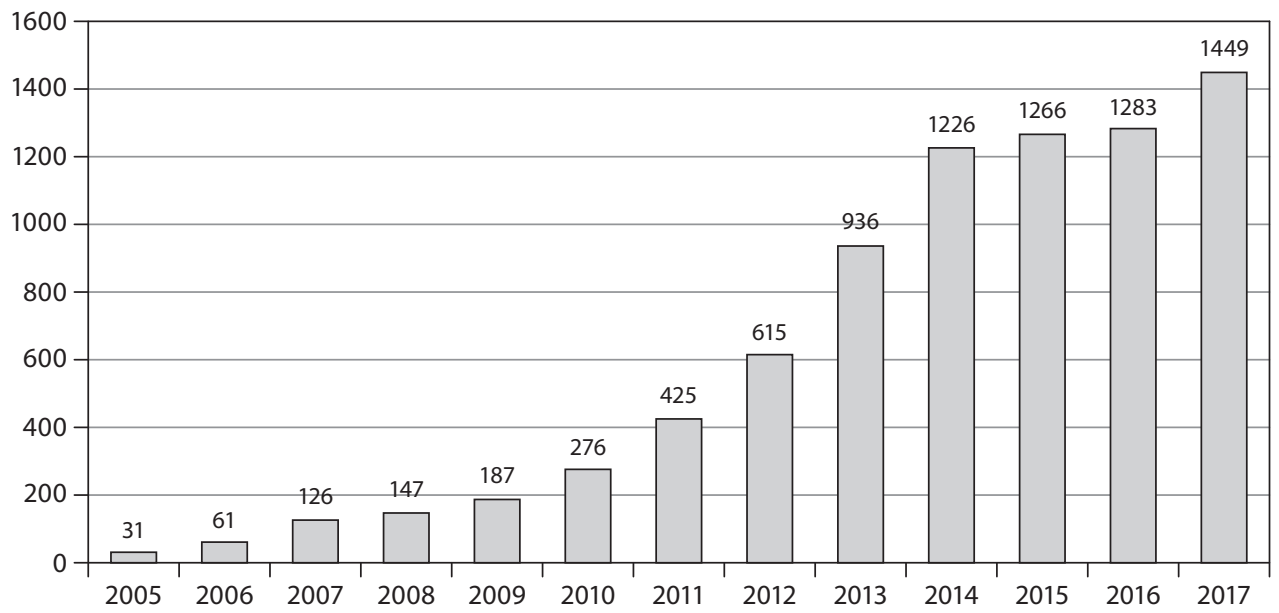

Wykres 1. Liczba spółdzielni socjalnych w Polsce w latach 2005-2017

Źródło: opracowanie własne na podstawie: Ogólnopolski Katalog Spółdzielni Socjalnych (2019).

Liczba zarejestrowanych spółdzielni wykazuje duże zróżnicowanie regionalne, które konsekwentnie utrzymuje się w kolejnych latach (wykres 2).

Różnice w liczbie spółdzielni w poszczególnych województwach były widoczne nie tylko w 2013 roku, ale utrzymały się także do roku 2017. W czołówce znalazły się województwa: wielkopolskie, mazowieckie i śląskie, a więc te charakteryzujące się dynamicznym rozwojem gospodarczym oraz wysoką aktywnością i przedsiębiorczością społeczności lokalnych. Najmniej spółdzielni występowało i występuje w województwach: podlaskim, opolskim i świętokrzyskim. Takie rozmieszczenie spółdzielni wskazuje jednak, że nie powstają one tam, gdzie byłyby najbardziej potrzebne, a więc na obszarach zagrożonych marginalizacją czy wysokim bezrobociem, tylko tam, gdzie prawdopodobnie podmioty zakładające spółdzielnie socjalne wykazują się większą sprawnością w pozyskiwaniu dotacji na prowadzenie działalności. 


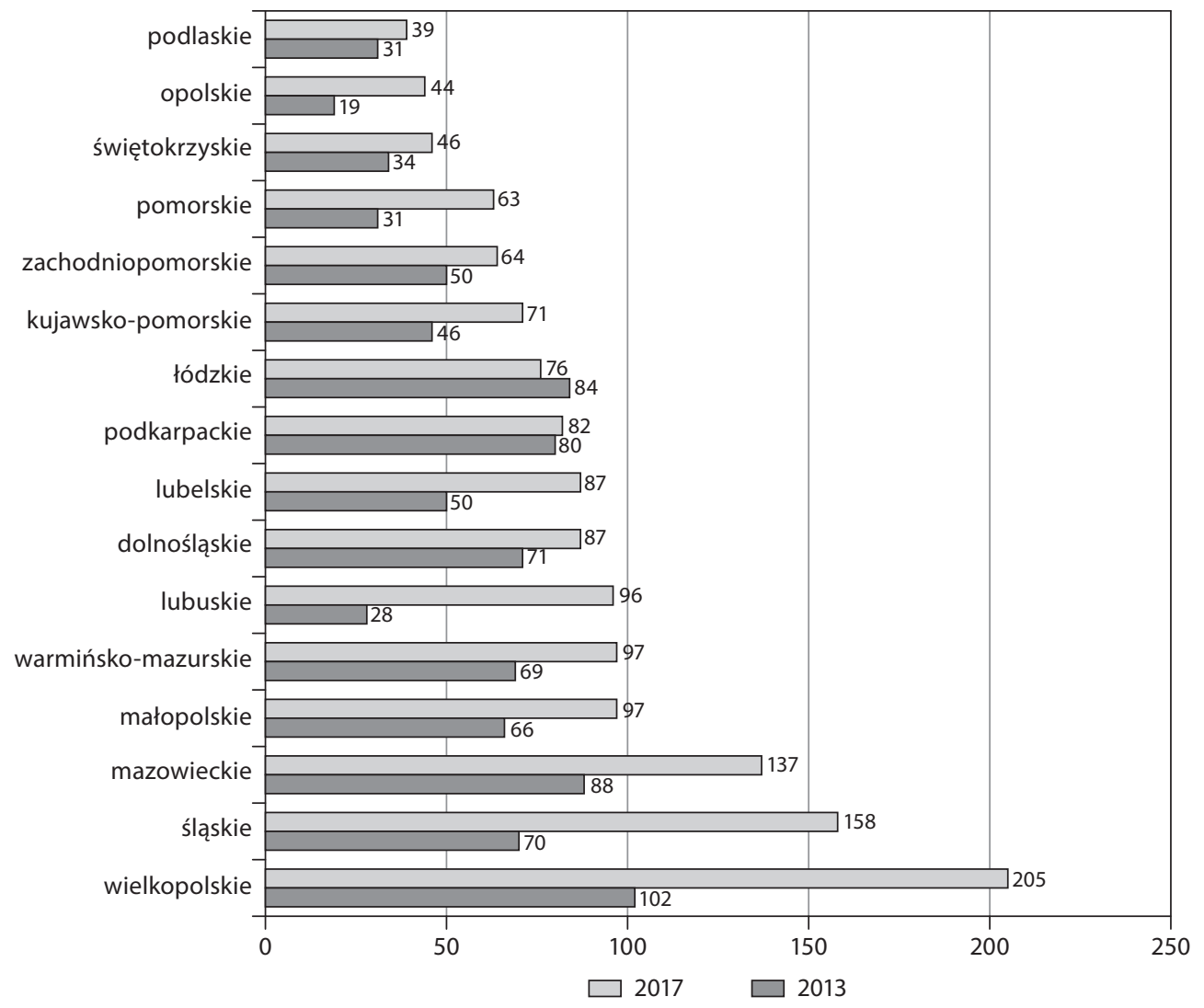

Wykres 2. Liczba spółdzielni socjalnych według województw w latach 2013 r. i 2017 r.

Źródło: opracowanie własne na podstawie: Informacja o funkcjonowaniu spółdzielni... (2015; 2018).

Jeśli chodzi o liczbę zarejestrowanych spółdzielni socjalnych podawane wielkości mogą uwzględniać także podmioty pozostające w likwidacji oraz te, które nie generują przychodów ani nie wykazują zatrudnienia. Według informacji z GUS w 2016 r., spośród 1,4 tys. spółdzielni socjalnych zarejestrowanych w REGON, GUS zweryfikował jako aktywnie działające 0,9 tys. podmiotów, czyli 62\% (Informacja o funkcjonowaniu spółdzielni..., 2018, s. 21).

Najważniejszym zadaniem spółdzielni socjalnych jest oczywiście tworzenie nowych miejsc pracy i aktywizowanie osób dotychczas nieaktywnych zawodowo. Rolą spółdzielczości socjalnej jest próba połączenia gospodarowania z budowaniem więzi społecznych. „Możliwość pracy i korzystania z wypracowanych własnym wysiłkiem środków finansowych podnosi poczucie własnej wartości, przywraca poczucie sprawstwa i kontroli nad swoim życiem, zwiększa wiarę w możliwość przezwyciężenia życiowych problemów" (Frączek i Laurisz, 2012, s. 162). W przeciwieństwie do innych form wspierania bezrobotnych, biednych czy wykluczonych, ekonomia społeczna nie utrwala zastanej sytuacji, ale stara się zmieniać mentalność osób nauczonych „brania”, uczy zaradności, wzajemnego zaufania i angażowania się dla wspólnego dobra. Dobro wspólne zaspokajające życiowe potrzeby indywidualne członków spółdzielni nabiera 
rzeczywistego wymiaru, w sytuacji uzyskiwania przez podmiot spółdzielczy dodatnich wyników finansowych w rezultacie prowadzonej działalności gospodarczej (Zubek, 2013, s. 549).

W spółdzielniach socjalnych na koniec 2017 r. zatrudnionych było 5,5 tys. pracowników etatowych. Średnio na jedną spółdzielnię socjalną zatrudniającą osoby na podstawie umowy o pracę przypadało 7 pracowników, przy czym połowa spółdzielni socjalnych nie zatrudniała więcej niż 5 osób. Wśród etatowych pracowników spółdzielni najczęściej znajdowały się osoby z wykształceniem średnim, policealnym lub pomaturalnym (37,2\%). Pracownicy z wykształceniem zasadniczym zawodowym stanowili 30,7\%, a z wykształceniem wyższym 21,8\%. Udział kobiet wśród osób zatrudnionych w spółdzielniach socjalnych kształtował się na poziomie 58,3\%, zaś udział osób niepełnosprawnych wynosił 29,6\% (Goś-Wójcika i in., 2019, s. 20).

Chociaż spółdzielnie socjalne wpisują się w ideę innowacji społecznej, z reguły same nie podejmują działalności o charakterze innowacyjnym, gdyż zgodnie z ustawą, nie jest to głównym celem ich działalności. Spółdzielcy objęci badaniami za lata 2012-2013, 2014-2015 oraz 2016-2017, konsekwentnie wskazują, że wybór obszaru działalności gospodarczej w największym stopniu determinowany był posiadanym przez jej członków wykształceniem i umiejętnościami oraz rozeznaniem rynkowym, badaniem popytu. W badaniach za rok 2012-2013 (Informacja o funkcjonowaniu spółdzielni..., 2015, s. 67) wskazywano głównie działalność związaną z:

- zakwaterowaniem i usługami gastronomicznymi - 18,3\%;

- opieką zdrowotną i pomocą społeczną - 15,3\%;

- inną działalnością usługową - 13,7\%;

- edukacją - 13\%.

W roku 2014 badając obszary działalności spółdzielni socjalnych odniesiono się do działów wymienionych w Polskiej Klasyfikacji Działalności. Wśród deklarowanych głównych obszarów działalności były (Informacja o funkcjonowaniu spółdzielni, 2016, s. 53):

- pozostała działalność usługowa - 30,3\%;

- działalność usługowa związana z wyżywieniem - 25,2\%;

- działalność usługowa związana z utrzymaniem porządku w budynkach i zagospodarowaniem zieleni - 16,5\%;

- edukacja - 13\%.

W 2017 r. spółdzielnie socjalne najczęściej prowadziły działalność związaną z zakwaterowaniem i usługami gastronomicznymi (21,4\%), następnie - usługami administrowania (20,3\%). Ponadto deklarowały usługi z zakresu opieki zdrowotnej i pomocy społecznej, w tym wsparcie bez zakwaterowania dla osób w podeszłym wieku i osób niepełnosprawnych oraz usługi związane z opieką dzienną nad dziećmi. Ten profil działalności spółdzielni socjalnej służy przede wszystkim zaspokajaniu potrzeb ludności w zakresie dostępu do usług społecznych użyteczności publicznej, a także pełni funkcję w zakresie reintegracji społecznej i zawodowej osób z grup narażonych na wykluczenie społeczne oraz odpowiada zapotrzebowaniu na te deficytowe usługi, działając w zgodzie z polityką prorodzinną, prozatrudnieniową i wspierającą osoby niepełnosprawne. Tym samym spółdzielczość socjalna wypełnia ważną rolę w usuwaniu bariery rozwoju lokalnego, jaką jest niedobór usług społecznych.

Na przeszkodzie skutecznego wypełniania przez spółdzielnie socjalne zadania, polegającego na nowatorskim rozwiązywaniu problemów społecznych stoi ich kondycja finansowa. Analizując strukturę spółdzielni pod kątem wyników finansowych można zauważyć negatywne zjawisko, które obrazuje wykres 3.

Konsekwentnie, pomimo upływu czasu, prawie 40\% spółdzielni generuje straty, a ponad $30 \%$ odnotowuje przychody na poziomie poniesionych kosztów. Obraz sytuacji dopełnia fakt, 
że $25 \%$ przychodów spółdzielni socjalnych stanowią przychody o charakterze nierynkowym, w przeważającym stopniu pochodzące ze źródeł publicznych, takich jak środki z UE i dofinansowanie do wynagrodzeń lub składek na ubezpieczenia społeczne pochodzące z Funduszu Pracy lub PFRON (Goś-Wójcicka i in., 2019, s. 28).

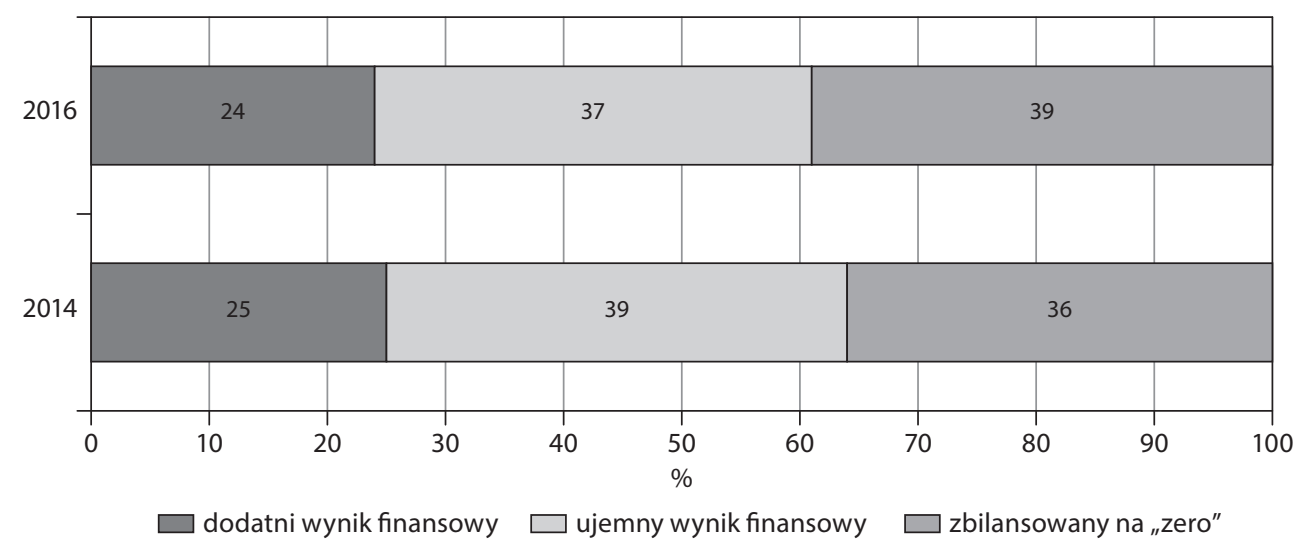

Wykres 3. Wyniki finansowe spółdzielni socjalnych w Polsce w 2014 r. i 2016 r.

Źródło: opracowanie własne na podstawie: Informacja o funkcjonowaniu spółdzielni... (2016; 2018).

Nie bez wpływu na wypełnianie swojej roli przez spółdzielnie socjalne pozostają liczne bariery rozwoju sektora, generowane przez samych spółdzielców, jak i czynniki zewnętrzne, takie jak: niespójność przepisów prawa, skomplikowane procedury zakładania i prowadzenia działalności w formie spółdzielni socjalnych, duże zróżnicowanie w intensywności korzystania ze wsparcia finansowego, nieefektywność niektórych form wsparcia, np. klauzul społecznych i zlecania zadań publicznych.

Niewątpliwie pracownicy spółdzielni socjalnych nie posiadają wystarczających kwalifikacji zawodowych, a kadra kierownicza ma niskie kompetencje menedżerskie. Widać tu najczęściej zupełną przypadkowość w doborze członków założycieli, a osoby wykluczone, które są zatrudniane w spółdzielni często prezentują postawę bierną i roszczeniową. Zbyt długie wcześniejsze pozostawanie poza rynkiem pracy powoduje brak motywacji i słabą umiejętność współpracy. Również profil działalności nie stanowi odpowiedzi na zapotrzebowanie rynku, raczej jest wybierany na podstawie posiadanych predyspozycji i umiejętności.

Wydaje się, że problemem może być fakt, że zarówno idea ekonomii społecznej, jak i spółdzielczości socjalnej są ideami nowymi, a to powoduje niski poziom wiedzy na ten temat wśród pracowników instytucji samorządowych i państwowych, co stanowi źródło braku zaufania do takiej formy działalności. Problemy te podniesione zostały $w$ analizie rozpoznawalności i kompetencji w obszarze ekonomii społecznej i solidarnej przeprowadzonej w Krajowym Programie Rozwoju Ekonomii Społecznej do 2023 roku (MRPiPS, 2019, s. 19). Taki też katalog zagrożeń został określony w badaniach za 2014 rok prowadzonych przez Departament Pożytku Publicznego MPiPS dla potrzeb cyklicznej sprawozdawczości prowadzonej na podstawie przepisów ustawy o spółdzielniach socjalnych (Informacja o funkcjonowaniu spółdzielni..., 2016, s. 48). Z badań tych wynika również, że spółdzielnie socjalne, niezależnie od tego czy zakładane są przez osoby fizyczne czy prawne, spotykają się z niechęcią i nieufnością innych podmiotów 
gospodarczych i innych instytucji otoczenia biznesu. Wsparcie finansowe również jest tu problematyczne, gdyż zwykle związane jest z bardzo restrykcyjnymi wymaganiami dotyczącymi otrzymania i zwrotu, jak np. uzyskanie poręczenie, które dla osób wykluczonych może być niemożliwe do wykonania. Skutkiem tego innowacyjny sposób rozwiązywania problemów społecznych poprzez tworzenie trwałych miejsc pracy w spółdzielniach socjalnych nie jest właściwie realizowany.

\section{Konkluzje}

W oparciu o przedstawione informacje i dane statystyczne można stwierdzić, że koncepcja spółdzielni socjalnych stanowi innowacyjne podejście do rozwiązywania problemów społecznych, szczególnie na lokalnych rynkach pracy. Innowacyjność ta polega na - poprzez aktywizację osób defaworyzowanych czy wykluczonych z rynku pracy - zwiększeniu podaży pracy i na wykorzystaniu potencjału osób, które mają szczególne trudności w powrocie na rynek pracy. Ma to wiele pozytywnych skutków, nie tylko na rynku pracy, ale również pozwala takim osobom na integrację społeczną. Innowacyjna rola spółdzielni socjalnych polega na odrębnych celach, które ma do osiągnięcia w porównaniu z przedsiębiorstwami standardowymi. Nie maksymalizacja zysku jest tu głównym motywem podjęcia działalności, ale stworzenie miejsc pracy dla osób, które nie mogą znaleźć pracy w innych przedsiębiorstwach. Nie chodzi tu o innowacje technologiczne czy organizacyjne, ale o rolę społeczną, którą spółdzielnia socjalna ma pełnić. Jest to widoczne nie tylko w realizacji procesu reintegracji społecznej i zawodowej, ale także w świadczeniu na rzecz lokalnej społeczności przez spółdzielnie socjalne usług takich jak, np.: usługi pomocy społecznej, opieki nad dziećmi i osobami starszymi. Z reguły są to usługi o charakterze deficytowym, więc podejmowanie tego profilu działalności przez spółdzielnie socjalne pozwala wypełnić lukę rynkową. Widać tu potencjał spółdzielni socjalnych, jednak praktyka pokazuje, że na skutek barier, które napotykają w swojej działalności, ich wpływ na rynek pracy i na lokalny rynek usług nie jest tak silny i trwały, jak można byłoby oczekiwać.

\section{Literatura}

Calsyn, R.J. (2003). A modified ESID approach to studying mental illness and homelessness. American Journal of Community Psychology, 32(3/4), 319-331.

Ekonomia społeczna w Polsce w nowej perspektywie finansowej 2020+. Wnioski i rekomendowane rozwiqzania (2019). Pobrane z: www.ekonomiaspoleczna.gov.pl/download/files/EKONOMIA_SPOLECZNA/ES_20212027.pdf (dostęp: 10.11.2019).

Frączek, M., Laurisz, N. (2012). Ekonomia społeczna a rynek pracy. W: M. Frączek, J. Hausner, S. Mazur (red.). Wokół ekonomii społecznej (s. 155-193). Kraków: Małopolska Szkoła Administracji Publicznej Uniwersytetu Ekonomicznego w Krakowie.

Goś-Wójcicka, K., Jarębska, K., Lewandowski, K., Makowska-Belta, E., Stasiak-Jaśkiewicz, U., Sekuła, T. (2019). Spółdzielnie jako podmioty ekonomii społecznej w 2017 r. Warszawa: GUS. Pobrane z: https://bip.stat.gov.pl/ dzialalnosc-statystyki-publicznej/projekty-unijne-w-statystyce/zintegrowany-system-monitorowaniasektora-ekonomii-spolecznej-zsmses/wyniki-badan/spoldzielnie-jako-podmioty-ekonomii-spolecznej-w-2017/ (dostęp: 10.11.2019).

Góźdź, D. (2008). Wyjaśnienie podstawowych pojęć z dziedziny ekonomii społecznej i przedsiębiorczości społeczne. W: D. Kwiecińska, A. Pacut (red.). Budowanie kompetencji dla przedsiębiorczości społecznej: sylabusy do szkoleń (s. 203-209). Kraków: Małopolska Szkoła Administracji Publicznej Uniwersytetu Ekonomicznego w Krakowie.

Hausner, J., Laurisz, N. (2006). Czynniki krytyczne tworzenia przedsiębiorstw społecznych. Przedsiębiorstwo społeczne. Konceptualizacja. W: J. Hausner (red.). Przedsiębiorstwa społeczne w Polsce. Teoria i praktyka (s. 9-30). Kraków: Małopolska Szkoła Administracji Publicznej Uniwersytetu Ekonomicznego w Krakowie. 
Informacja o funkcjonowaniu spółdzielni socjalnych działajacych na podstawie ustawy z dnia 27 kwietnia 2006 r. o spółdzielniach socjalnych za lata 2010-2011 (2012). Druk sejmowy nr 738 z 2012 r. Pobrane z: www.sejm.gov. pl/sejm7.nsf/PrzebiegProc.xsp?nr=738\&SessionID=DMU1FYLX7V (dostęp: 10.11.2019).

Informacja o funkcjonowaniu spółdzielni socjalnych działajacych na podstawie ustawy z dnia 27 kwietnia 2006 r. o spółdzielniach socjalnych za lata 2012-2013 (2015). Druk sejmowy nr 3166 z 2015 r. Pobrane z: www.sejm. gov.pl/sejm7.nsf/druk.xsp?nr=3166 (dostęp: 10.11.2019).

Informacja o funkcjonowaniu spółdzielni socjalnych działających na podstawie ustawy z dnia 27 kwietnia 2006 r. o spółdzielniach socjalnych za lata 2014-2015 (2016). Druk sejmowy nr 777 z 2016 r. Pobrane z: www.sejm. gov.pl/sejm8.nsf/druk.xsp?nr=777 (dostęp: 10.11.2019).

Informacja o funkcjonowaniu spółdzielni socjalnych działających na podstawie ustawy z dnia 27 kwietnia 2006 r. o spółdzielniach socjalnych za lata 2016-2017 (2018). Druk sejmowy nr 2724 z 2018 r. Pobrane z: www.sejm. gov.pl/sejm8.nsf/druk.xsp?documentld=08058DD855E949FFC12582C10039EC63 (dostęp: 10.11.2019).

Jędrych, E. (2013). Inwestowanie w innowacje społeczne w organizacjach gospodarczych. Warszawa: Wydawnictwo Naukowe PWN.

MRPiPS (2019). Krajowy Program Rozwoju Ekonomii Społecznej do 2023 roku. Ekonomia Solidarności Społecznej. Ministerstwo Rodziny, Pracy i Polityki Społecznej Warszawa, załącznik do uchwały Rady Ministrów z dnia 31 stycznia 2019 r. (poz. 214).

Maruyama, Y., Nishikido, M., lida T. (2007). The rise of community wind power in Japan: Enhanced acceptance through social innovation. Energy Policy, 35, 2761-2769.

Morawska-Jancelewicz, J. (2016). Innowacje społeczne w miastach europejskich. Przykłady dobrych praktyk. Studia Miejskie, 23(6), 65-79.

Ogólnopolski Katalog Spółdzielni Socjalnych (2019). Pobrane z: www.spoldzielniesocjalne.org (dostęp: 19.12.2019).

Pearce, J. (2003). Social Enterprise in Anytown. London: Calouste Gulbenkian Foundation.

Praszkier, R., Nowak, A. (2005). Zmiany społeczne powstałe pod wpływem działalności przedsiębiorców społecznych. Trzeci Sektor, 2, 140-157.

Prognoza ludności na lata 2014-2050 (2014). Warszawa: Główny Urząd Statystyczny.

Skubiak, B. (2016). Innowacje społeczne w teorii i praktyce. Barometr Regionalny, 14, 29-33. Pobrane z: http:// br.wszia.edu.pl/zeszyty/pdfs/br43_04skubiak.pdf (dostęp: 15.11.2019).

Sullivan, C.M. (2003). Using the ESID model to reduce intimate male violence against women. American Journal of Community Psychology, 32(3-4), 295-303.

Szczepańczyk, M. (red.) (2017). Innowacje społeczne w teorii i praktyce. Monografie Politechniki Łódzkiej, Łódź: Wydawnictwo Politechniki Łódzkiej.

Tafel-Viia, K., Loogma, K., Lassur, S., Roosipõld, A. (2012). Networks as agents of innovation: teacher networking in the context of vocational and professional higher education reforms. Vocations and Learning, 5(2), 175-193.

Ustawa z dnia 27 kwietnia 2006 r. o spółdzielniach socjalnych, Dz.U. z 2006 r. nr 94, poz. 651 ze zm.

Wronka-Pośpiech, M. (2015). Innowacje społeczne - pojęcie i znaczenie. Studia Ekonomiczne, 212, 124-136.

Zubek, M. (2013). Efektywność finansowa spółdzielczego podmiotu gospodarki społecznej gwarantem jej bytu społecznego? Zarządzanie i Finanse, 1(2), 547-562.

Związek Przedsiębiorców i Pracodawców (2016). Raport. Imigranci z Ukrainy ratunkiem dla polskiej demografii. Warszawa: ZPP.

\section{The social cooperative as an innovative form of action for solving social problems}

Summary: Both social economy and social innovations are issues that nowadays often intertwine, and can become the instruments that are effective in solving social-economic problems. This paper is dedicated to innovative approaches in solving the social problems through social innovations, particularly social cooperatives, which play an important role in social reintegration. The goal of the paper is to deliver a review on the role of social cooperatives in solving local social problems in Poland. The research was conducted through a thorough analysis of the publications and documents that relate to social enterprises and social cooperativity. In the conclusion it is stated, that social cooperative conception is an innovative approach in solving social problems, especially in the local labour market and in counteracting social services deficiencies. Findings suggest that the effectiveness of social cooperatives is limited by the difficult financial situation of the subjects, and numerous internal and the external barriers.

Keywords: social economy; social cooperative; social innovation; exclusion; reintegration

JEL codes: J79; L73 


\section{Informacje o autorach}

\section{Dorota Koptiew*}

ORCID: 0000-0002-7824-4107

Katedra Ekonomii

Wydział Administracyjno-Ekonomiczny

Państwowa Wyższa Szkoła Zawodowa

ul. Mickiewicza 11, 33-100 Tarnów

e-mail: dorotakoptiew@autograf.pl

* autor korespondencyjny
Bogusława Puzio-Wacławik

ORCID: 0000-0001-8192-8174

Katedra Ekonomii

Wydział Administracyjno-Ekonomiczny

Państwowa Wyższa Szkoła Zawodowa

ul. Mickiewicza 11, 33-100 Tarnów

e-mail: b_puzio-waclawik@pwsztar.edu.pl

\section{Prawa autorskie i licencja / Copyright and License}

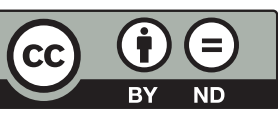

Publikacja na licencji Creative Commons Uznanie autorstwa Użycie niekomercyjne - Bez utworów zależnych 4.0 Międzynarodowe (CC BY-ND 4.0) http://creativecommons.org/licenses/by-nc-nd/4.0/deed/pl

This work is published under the terms of the Creative Commons Attribution - NoDerivetives International (CC BY-ND 4.0) License http://creativecommons.org/licenses/by-nc-nd/4.0

Wydane przez Uniwersytet Ekonomiczny w Krakowie.

Małopolska Szkoła Administracji Publicznej

Published by Cracow University of Economics - Krakow, Poland. Małopolska School of Public Administration of the Cracow University of Economics 